\title{
A Survey of Total $\beta$-glucan Content in Croatian Barley Varieties
}

\author{
V. Krstanović ${ }^{1}$, A. Lalić3 ${ }^{3}$ I. Kosović ${ }^{2}$, N. Velić ${ }^{1}$, \\ Kristina MastanjeVić ${ }^{1 *}$ and K. MastanjeVić ${ }^{2}$ \\ ${ }^{1}$ Department of Process Engineering, Faculty of Food Technology, University of J.J. Strossmayer Osijek, \\ F. Kuhača 18, 31000 Osijek, Croatia \\ ${ }^{2}$ Department of Food Technology, Faculty of Food Technology, University of J.J. Strossmayer Osijek, \\ F. Kuhača 18, 31000 Osijek, Croatia \\ ${ }^{3}$ Institute of Agriculture Osijek, Južno predgrađe 17, 31000 Osijek, Croatia
}

(Received 11 November 2015; Accepted 14 April 2016;

Communicated by H. Grausgruber)

\begin{abstract}
Although $\beta$-glucans in cereals are desirable as healthy diet components, high levels of $\beta$-glucans in malting barley are unacceptable because they can cause unsatisfactory degradation of cell walls during malting. The aim of this study was to investigate the $\beta$-glucan content in twelve Croatian and two German barley varieties at three representative locations in Eastern Croatia over three consecutive seasons (2012-2014). Total $\beta$-glucan content in barley samples was determined using enzymatic method. Most of the investigated barley varieties had total $\beta$-glucan content lower or significantly lower than $4 \%$. Furthermore, a distinct and clear genotype influence was noticed. No significant difference was found between years, but between locations Osijek and Tovarnik.
\end{abstract}

Keywords: Hordeum vulgare, brewing, feed barley, malting barley

\section{Introduction}

In recent years, researchers have shown an increased interest in $\beta$-glucans because of their beneficial effects on human health. Degradation products of $\beta$-glucans larger than glucose will not be absorbed in the human body, so they represent a valuable source of soluble fibre (Kanauchi et al. 2011). From a human nutrition perspective, $\beta$-glucans can be characterised as prebiotics (Bamforth and Gambill 2007). However, from brewers' perspective, $\beta$-glucans are not desirable in cereals intended for malting and brewing.

$\beta$-Glucans are non-starch polysaccharides characterized by $(1 \rightarrow 3),(1 \rightarrow 4) \beta$-D-glucose linkage. They are the main components of the endosperm cell walls and can be mostly found in barley and oats, while in other cereals they are present to a significantly lesser extent (Vis and Lorenz 1997). Total content of $\beta$-glucans in barley normally ranges from 2 to $8 \%$ (Marconi et al. 2014) and depends predominantly on genetic factors, but other factors (e.g. climatic conditions, agro-technical measures, soil type) also contribute to the total $\beta$-glucan content in barley (Aastrup 1979; Narziss et al. 1989; Zhang et al. 2001).

*Corresponding author; E-mail: khabschi@ptfos.hr 
$\beta$-Glucans are considered useful when they appear in small amounts in malted cereals used for brewing, because they contribute to beer foam stability and improve beer organoleptic properties (i.e. beer mouth feel) (Havlová et al. 2006). However, when present in higher amounts they cause serious problems during both malting and brewing. During malting, high $\beta$-glucan content can lead to unsatisfactory degradation of cell walls, which disrupts the germination and reduces the malt extract (Wang et al. 2004). $\beta$-Glucan residues in malt can lead to poor mash conversion, resulting in highly viscous wort. This ultimately can cause problems during the filtration process (Vis and Lorenz 1998; Wang et al. 2004) and induce haze in the final product, i.e. beer (Jin 2002).

For that reason, barley with low to moderate $\beta$-glucans content is preferable for malt production (Vis and Lorenz 1998). Furthermore, the existing research results suggest the use of six-rowed barley that seems to have somewhat lower $\beta$-glucan content than tworowed varieties (Lehtonen and Aikasalo 1987; Zhang et al. 2001). Based on their intended use in respect to their characteristics, barley varieties in Croatia can be classified as 'malting', 'feed' and 'malting-feed'. Most of the varieties are winter varieties with somewhat higher yields $(+30 \%)$ and lower costs compared to spring barley. However, in order to be acceptable for malting/brewing, the main quality parameters have to be suitable, such as $\beta$-glucan content, protein content, friability, glassy grains percentage.

Because of the quality parameters that are important for brewers, some winter barley varieties are labelled as malting-feed varieties (Kunze 1996). Dual-purpose and higher yields, compared to malting barley varieties, make these varieties attractive to barley growers. Upon the entry into the EU the Croatian market has opened to malting barley varieties originating from EU countries which meet the strict quality criteria set for malt and beer. According to the above-mentioned criteria, domestic malting varieties were not suitable for brewing. Therefore, the Croatian Varietal Commission has allowed dual-purpose labelling of varieties that were primarily registered as livestock feed.

The objective of this study was to determine the total $\beta$-glucans content in 14 barley varieties collected at three locations over three consecutive seasons (2012-2014). The acquired data could serve maltsters as important input information upon the admission of barley to the Croatian malting industry.

\section{Materials and Methods}

\section{Samples}

Croatian winter barley varieties of different traits (e.g. maturity, plant height, straw strength, lodging tolerance, biotic and abiotic stress tolerance, etc.) and grain properties were selected based on previous studies (Lalić et al. 2006, 2007; Kovačević et al. 2008) and on their importance for industry over the last decade.

Samples of 14 different varieties were collected over three consecutive seasons (20122014) from the variety trials of the Agricultural Institute, Osijek. The barley varieties were grown under field conditions on three localities, i.e. Osijek (OS), Slavonski Brod (SB) and Tovarnik (TO) over three growing (vegetation) seasons (2011/12, 2012/13 and 
Table 1. Soil properties, precipitation and mean temperature during the growing season of winter barley (October-June) at the three test sites

\begin{tabular}{|c|c|c|c|}
\hline & Osijek & Slavonski Brod & Tovarnik \\
\hline Latitude & $45^{\circ} 27^{\prime} \mathrm{N}$ & $45^{\circ} 10^{\prime} \mathrm{N}$ & $45^{\circ} 10^{\prime} \mathrm{N}$ \\
\hline Longitude & $18^{\circ} 48^{\prime} \mathrm{E}$ & $18^{\circ} 01^{\prime} \mathrm{E}$ & $19^{\circ} 09^{\prime} \mathrm{E}$ \\
\hline Soil type & eutric cambisol & alluvial soil & hipogley \\
\hline Soil pH & 6.25 & 4.2 & 7.1 \\
\hline \multicolumn{4}{|l|}{ Rainfall (mm) } \\
\hline $2011 / 12$ & 392.3 & 419.5 & 332.4 \\
\hline $2012 / 13$ & 679.0 & 647.2 & 625.3 \\
\hline $2013 / 14$ & 573.2 & 567.9 & 460.9 \\
\hline \multicolumn{4}{|c|}{ Mean temperature $\left({ }^{\circ} \mathrm{C}\right)$} \\
\hline $2011 / 12$ & 8.3 & 8.3 & 8.9 \\
\hline $2012 / 13$ & 9.1 & 9.1 & 9.6 \\
\hline $2013 / 14$ & 10.2 & 9.9 & 10.8 \\
\hline
\end{tabular}

2013/14). The experiments were conducted in randomized block designs (RCBD) with six replications; plot size was $7.56 \mathrm{~m}^{2}$. Soil properties and climatic conditions during the growing seasons at the respective locations are displayed in Table 1.

Sampling ( $5 \mathrm{~kg}$ per sample) was performed on cleaned and processed barley grains (according to the EBC 3.3.1. method) and the samples were kept refrigerated in sterile dry containers. Almost all varieties are two-rowed varieties from the Agricultural Institute Osijek, except Lord which is six-rowed; Tiffany and Vanessa on the other hand were originally bred in Germany.

\section{Determination of total $\beta$-glucan content}

First the barley samples were milled using a standard laboratory mill with a $1 \mathrm{~mm}$ sieve (MF10.2 basic, IKA Labortechnik, Germany) and after that using a kitchen coffee grinder (Braun KMM 10). The grinded samples were kept in sealed plastic bags until the enzymatic determination of total $\beta$-glucan content (AOAC 1995) using a commercial assay kit (Mixed linkage $\beta$-glucan assay kit, Megazyme Int., Bray, Ireland).

\section{Statistical analysis}

Analysis of variance (ANOVA) was carried out using the GLM procedure of SAS Vers. 8 software (SAS Inst., Cary, NC). Mean comparisons were done using Fisher's least significant difference (LSD) test.

Values of the main effects and the first interaction axis for interpretation of genotype $\times$ environment interaction were presented in graphic representation-biplot anal- 


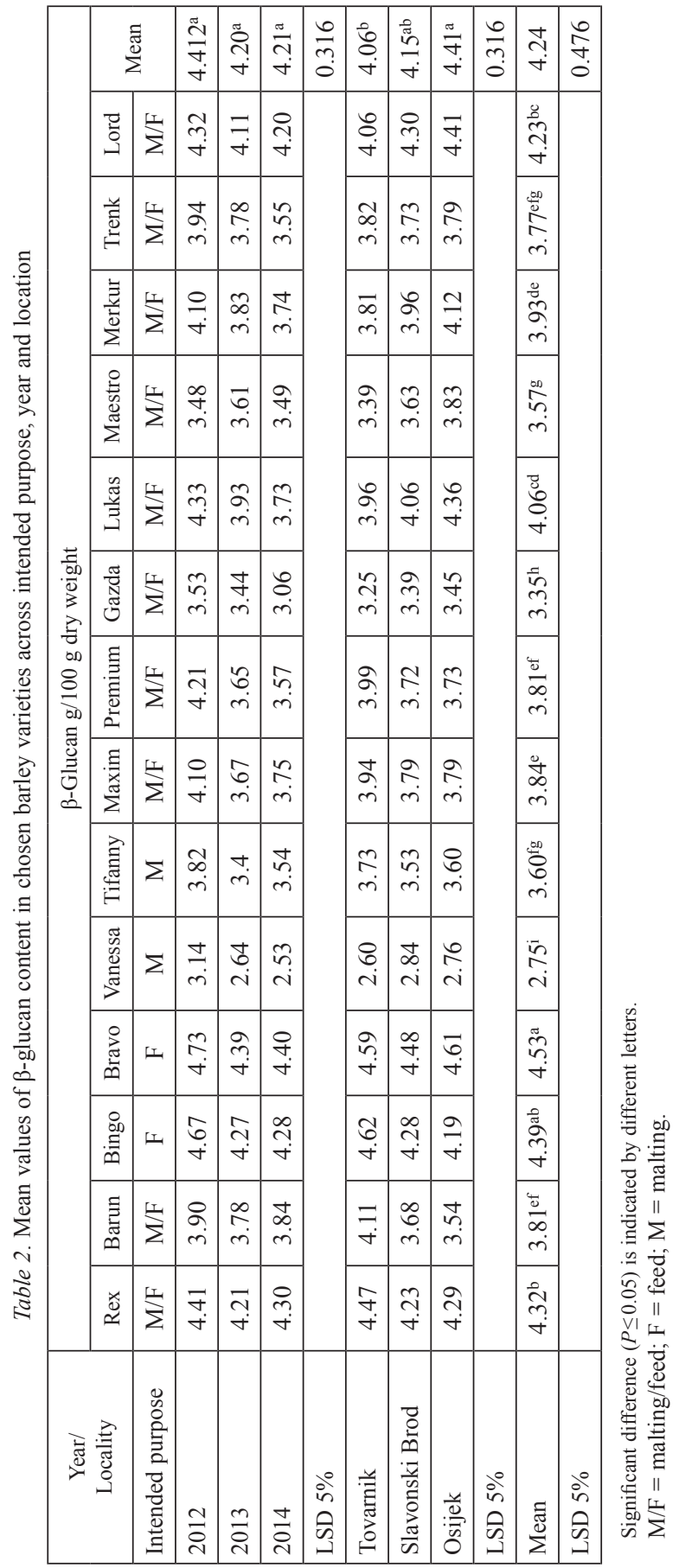

Cereal Research Communications 44, 2016 
ysis of GGE model, and biplot for 9 environments and 14 cultivars of winter barley was constructed.

The software PBTools, version 1.4. 2014. (Biometrics and Breeding Informatics, PBGB Division, International Rice Research Institute, Los Baños, Laguna, Philippines) was used for GGE biplot analysis.

\section{Results}

Mean values of total $\beta$-glucan content are presented in Table 2. ANOVA revealed no significant difference between years, but significant differences between genotypes and locations.

Figure 1 gives GGE-biplot for 14 barley genotypes grown in 9 diversified environments. The $\mathrm{G} \times \mathrm{E}$ visualization by the GGE biplot revealed that Vanessa is less influenced by the locations and exhibits a high negative PC1 score which indicates the lowest $\beta$-glucan content. Tiffany, the second German winter barley suitable for malting/brewing showed also stable performance across locations, however, somewhat higher $\beta$-glucan content. A similar performance showed the Croatian varieties Gazda, Trenk and Maestro and with respect to the $\beta$-glucan content also Premium, Maxim and Barun. The latter two, however, were somewhat more sensitive to the environmental influence. Therefore, these Croatian varieties had $\beta$-glucan contents satisfactory for the malting industry (i.e. $<4 \%$ ).

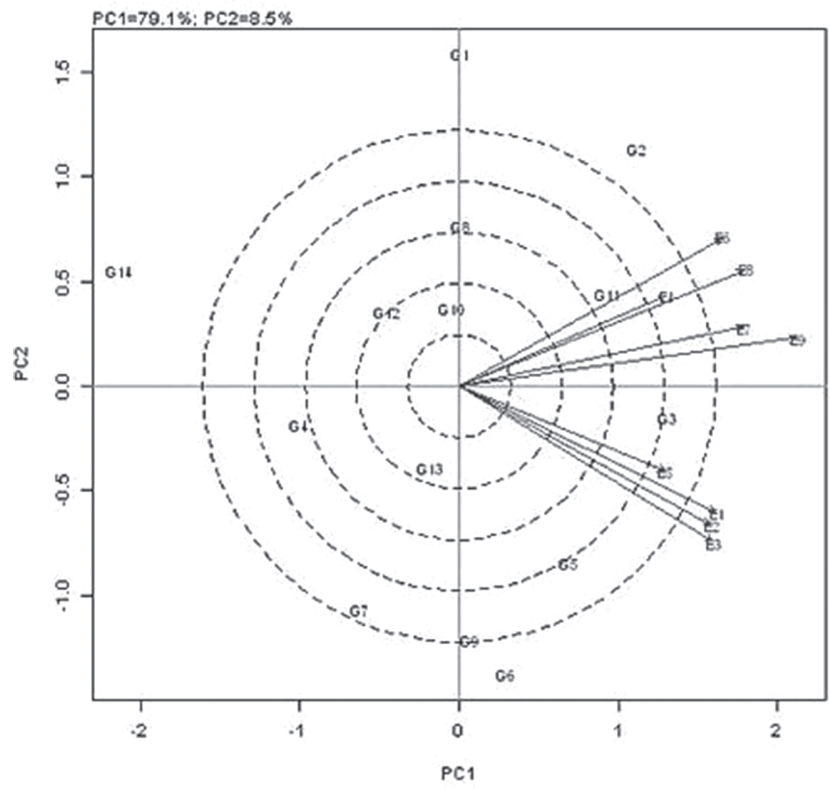

CODES USED IN GRAPHS:

Genotype Code

Barun G1

Bingo G2

Bravo G3

Gazda G4

Lord G5

Lukas G6

Maestro G7

Maxim G8

Merkur G9

Premium G10

Rex G11

Tifanny G12

Trenk G13

Vanessa G14

Environment Code

Osijek 2011 E1

Osijek 2012 E2

Osijek 2013 E3

Slavonski Brod 2011 E4

Slavonski Brod 2012 E5

Slavonski Brod 2013 E6

Tovarnik 2011 E7

Tovarnik 2012 E8

Tovarnik 2013 E9

Figure 1. GGE-biplot for 14 barley genotypes grown in 9 diversified environments 
Dual purpose (malting/feed) varieties Lord, Lukas, Merkur and Rex had not only somewhat higher $\beta$-glucan contents but also a more unstable performance. The varieties which were registered as feed varieties (i.e. Bingo and Bravo) had not only the highest $\beta$-glucan contents, but also an unstable performance across locations. Results also indicate that Osijek is most suitable for barley growing, as far as low $\beta$-glucan content is concerned.

\section{Discussion}

The adaptability of a variety to different growing conditions and a genotype's reaction to biotic and abiotic stresses are significant factors for the success of a variety. In Croatia, high temperatures during May and June can affect the grain filling period and cause premature ripening of the grain (Lalić et al. 2006). In barley, premature ripening can cause an increase of the total $\beta$-glucan content (Passarella et al. 2002). The content of $\beta$-glucans is affected by both the genotype and the environment, genetic factors, however, are more important (Molina-Cano et al. 1997; Zhang et al. 2001). Furthermore, it is considered that after longer cultivation under the same growing conditions $\beta$-glucan high-molecular components (the most problematic in brewing) become genotypically determined, i.e. become a variety trait (Narziss 1989). Although the above-mentioned statement is commonly accepted by maltsters and is often cited in professional literature, geneticists and barley breeders think this should be confirmed by scientific research methods.

Considering the total $\beta$-glucan content, it should be taken into account that during malting $\beta$-glucan content decreases proportionally to the increase of grain friability (Henry 1988). $\beta$-Glucan degradation takes place at germination (malting) temperatures which is the only period in which enzymes degrade $\beta$-glucans. The solubility of $\beta$-glucans is greatly affected by the structure and interrelations of certain $\beta$-glucan fractions. Highmolecular compounds are especially problematic for brewing (Kanauchi et al. 2011), therefore, low $\beta$-glucan content in grains is required by maltsters and brewers. The $\beta$-glucan content in grains correlates with $\beta$-glucan concentration in wort. Brewing technology itself contributes also to the final $\beta$-glucan content in wort. Edney et al. (2012, 2014) reported wort $\beta$-glucan content ranging from 60 to $140 \mathrm{mg} / \mathrm{L}$ for Canadian barley varieties. Even though there are no recommendations for brewers regarding total $\beta$-glucan content in malt, for wort it is recommended it should not exceed $200 \mathrm{mg} / \mathrm{L}$ (Davis 2006).

The American Malting Barley Association is even more stringent and recommends $\beta$-glucan concentrations in wort of $<100 \mathrm{mg} / \mathrm{L}$ for two-row barley and $<120 \mathrm{mg} / \mathrm{L}$ for sixrow barley (Davis 2014). In everyday practice higher values are also tolerated, e.g. IGB (Institute \& Guild of Brewing) sets the limit at $<200 \mathrm{mg} / \mathrm{L}$ (O'Rourke 2002), while EBC (European Brewery Convention) sets it at $<250 \mathrm{mg} / \mathrm{L}$. However, often these recommended values are not achieved because the total $\beta$-glucan content of the raw material is often around 4\% (MEBAK 1997; EBC 1998).

The results of this study showed that Croatian barley varieties classified as feed varieties had the highest total $\beta$-glucan content, while German malting varieties had the lowest total $\beta$-glucan content. The total $\beta$-glucan content of the majority of Croatian winter barley varieties which were classified as dual-purpose malting-feed varieties was $<4 \%$, how- 
ever, some showed an increased instability with respect to their reaction to the environment. Gazda, Trenk and Maestro were identified as suitable for malting with respect to their low $\beta$-glucan content and their environmental stability.

Looking at environmental stability, it is visible from the results of GGE-biplot (Fig. 1) that Osijek (eutric cambisol) is most suitable for barley growing, showing almost no fluctuations across the years. Tovarnik (hypogley) also gave good results for barley stability, but Slavonski Brod (alluvial soil) was most unstable across the years. Eventhough $\beta$-glucan content is considered to be genotypically determined trait, this research showed that soil type in Osijek, an eutric cambisol ( $\mathrm{pH}$ 6.25) appeared to be most suitable soil for barley growing if low $\beta$-glucan content is desirable. Since rainfall and temperatures (Table 1) were similar at all three locations across the years, it can be concluded that $\mathrm{pH}$ values and the soil type made a slight impact on the difference in $\beta$-glucan content of chosen barley genotypes. This is a very important piece of information for barley growers indicating that Osijek is most suitable for barley growing in order to realize stable $\beta$-glucan concentrations. Also, the genotypic stability of chosen varieties was not influenced by Osijek's and Tovarnik's soil as much as by Slavonski Brod's soil. However, more and extensive research should be conducted on this note.

\section{References}

Aastrup, S. 1979. The effect of rain on $\beta$-glucan content in barley grains. Carlsberg Res. Commun. 44:381-393. AOAC International 1995. Official methods of analysis of AOAC International, 16th ed. (Methods 992.28 and 995.16). The Association. Arlington, VA, USA.

Bamforth, C.W., Gambill, S.C. 2007. Fiber and putative prebiotics in beer. J. Am. Soc. Brew. Chem. 65:67-69.

Davis, M. 2014. Future of malting barley in North America: Keeping barley competitive with other crops. Master Brewers Association of the Americas, District Northern California \& District Southern California Joint Technical Conference, 24-25 October, Paso Robles, CA, USA. (http://www.mbaa.com/districts/ NorthernCalifornia/Documents/2014\%20Joint\%20Technical\%20Conference/2-1\%20M\%20Davis\%20 Future\%20of\%20Malting\%20Barley\%20in\%20N\%20America.pdf, accessed March, 2016)

Davis, N. 2006. Malt and malt products. In: Bamforth, C.W. (ed.), Brewing - New technologies. Woodhead Publishing Ltd., Cambridge, UK. pp. 68-101.

EBC 1998. Analytica, 5th ed. (Methods 3.3.1 and 4.16.1), European Brewery Convention. Fachverlag Hans Carl, Nürnberg, Germany.

Edney, M.J., MacLeod, A.L., LaBerge, D.E. 2014. Evolution of a quality testing program for improving malting barley in Canada. Can. J. Plant Sci. 94:535-544.

Edney, M.J., O’Donovan, J.T., Turkington, T.K., Clayton, G.W., McKenzie, R., Juskiw, P., Lafond, G.P., Brandt, S., Grant, C.A., Harker, K.N., Johnson E., May, W. 2012. Effects of seeding rate, nitrogen rate and cultivar on barley malt quality. J. Sci. Food Agric. 92:2672-2678.

Havlová, P., Lancova, K., Váňová, M., Havle, J., Hajšlová, J. 2006. The effect of fungicidal treatment on selected quality parameters of barley and malt. J. Agric. Food Chem. 54:1353-1360.

Henry, J. 1988. The carbohydrates of barley grains - a review. J. Inst. Brew. 94:71-78.

Jin, Y. 2002. Effect of $\beta$-glucan and environmental factors on the physical and chemical properties of wort and beer. $\mathrm{PhD}$ thesis, Dalhousie University, Halifax, Nova Scotia. (http://dalspace.library.dal.ca/handle/10222/55884; accessed 1 March 2016)

Kanauchi, M., Ishikura, W., Bamforth, C.W. 2011. $\beta$-Glucans and pentosans and their degradation products in commercial beers. J. Inst. Brew. 117:120-124.

Kovačević, J., Lalić, A., Jurković, Z. 2008. Characterization of winter barley genotypes in Croatian environment. Cereal Res. Commun. 36, S5; Pt. 3:1583-1586. 
Kunze, W. 1996. Technology - Brewing and Malting. 1st international edition. VLB. Berlin, Germany.

Lalić, A., Kovačević, J., Drezner, G., Novoselović, D., Babić, D., Dvojković, K., Šimić, G. 2006. Response of winter barley genotypes to Croatian environments - yield, quality and nutritional value. Cereal Res. Commun. 34:433-436.

Lalić, A., Kovačević, J., Šimić, G., Drezner, G., Guberac, V. 2007. Environmental effects on grain yield and malting quality parameters of winter barley. Cereal Res. Commun. 35:709-712.

Lehtonen, M., Aikasalo, R. 1987. Beta-glucan in two- and six-rowed barley. Cereal Chem. 64:191-193.

Marconi, O., Tomasi, I., Dionisio, L., Perretti, G., Fantozzi, P. 2014. Effects of malting on molecular weight distribution and content of water-extractable $\beta$-glucans in barley. Food Res. Int. 64:677-682.

MEBAK 1997. Brautechnische Analysenmethoden, 3rd ed., vol. I (Method 2.5.7.) (Analytical Methods of Brewing Techniques). Middle European Brewing Analysis Commission (MEBAK), Freising-Weihenstephan, Germany.

Molina-Cano, J.L., Francesch, M., Perez-Vendrell, A.M., Ramo, T., Voltts, J., Brufau, J. 1997. Genetic and environmental variation in malting and feed quality of barley. J. Cereal Sci. 25:37-47.

Narziss, L., Miedaner, H., Koch, M. 1989. Examination of volatile substances during malting and originating from thermal loading of the products. Part 2. Influence of the malting and mashing parameters. Monatsschr. Brauwiss. 42:232-242.

O’Rourke, T. 2002. Malt specifications and brewing performance. Technical Summary 10. Brewer Int. 2:27-30. https://www.ibd.org.uk/cms/file/314, accessed November 2015.

Passarella, V.S., Savin, R., Slafer, G.A. 2002. Grain weight and malting quality in barley as affected by brief periods of increased spike temperature under field conditions. Aust. J. Agric. Res. 53:1219-1227.

Vis, R.B., Lorenz, K. 1997. $\beta$-Glucans: importance in brewing and methods of analysis. Lebensm.-Wiss. Technol. 30:331-336.

Vis, R.B., Lorenz, K. 1998. Malting and brewing with a high $\beta$-glucan barley. Lebensm.-Wiss. Technol. 31:20-26.

Wang, J., Zhang, G., Chen, J., Wu, F. 2004. The changes of $\beta$-glucan content and $\beta$-glucanase activity in barley before and after malting and their relationship to malt qualities. Food Chem. 86:223-228.

Zhang, G., Chen, J., Wang, J., Ding, S. 2001. Cultivar and environmental effects on $(1 \rightarrow 3,1 \rightarrow 4)-\beta$-D-glucan and protein content in malting barley. J. Cereal Sci. 34:295-301. 